Bull. Chem. Soc. Ethiop. 2012, 26(3), 329-342.

Printed in Ethiopia

ISSN 1011-3924

DOI: http://dx.doi.org/10.4314/bcse.v26i3.2

(c) 2012 Chemical Society of Ethiopia

\title{
LEVELS OF ESSENTIAL AND NON-ESSENTIAL METALS IN RHAMNUS PRINOIDES (GESHO) CULTIVATED IN ETHIOPIA
}

\author{
Afewerk Gebre and Bhagwan Singh Chandravanshi ${ }^{*}$ \\ Department of Chemistry, Addis Ababa University, P.O. Box 1176, Addis Ababa, Ethiopia
}

(Received May 1, 2012; revised July 18, 2012)

\begin{abstract}
The objective of this study was to assess the levels of essential and toxic metals in leaf and stem of Rhamnus prinoides which are used for bitterness of local alcoholic beverages in Ethiopia and as traditional medicine in some African countries. Levels of essential metals (Ca, Mg, Cr, Mn, Fe, Co, Ni, Cu and $\mathrm{Zn}$ ) and toxic metals $(\mathrm{Cd}$ and $\mathrm{Pb})$ in the leaves and stems of Rhamnus prinoides (Gesho) cultivated in Ethiopia were determined by flame atomic absorption spectroscopy. Known weights $(0.5 \mathrm{~g})$ of dried samples were digested with the optimized mixture of $\mathrm{HNO}_{3}, \mathrm{H}_{2} \mathrm{O}_{2}$ and $\mathrm{HClO}_{4}$ on a Kjeldahl apparatus with a reflux condenser. The efficiency of the optimized procedure was validated by spiking experiment and the percentage recovery for all the metals was in the range of $92-103 \%$ for leaf samples and $91-103 \%$ for the stem samples. The levels $(\mathrm{mg} / \mathrm{kg})$ of the metals were found to be: $\mathrm{Ca}$ (6304-22236), Mg (3202-5706), Cr (5.08-20.6), Mn (8.12-17.9), Fe (47.9-187), Co (22.2-42.1), $\mathrm{Ni}$ (12.8-27.3), $\mathrm{Cu}(6.5-73.0), \mathrm{Zn}(12.2-43), \mathrm{Cd}(0.81-3.10)$, and $\mathrm{Pb}(17.7-25.0)$ in the leaf samples and $\mathrm{Ca}$ (3601-5675), $\mathrm{Mg}$ (2635-5528), Cr (ND-16.3), Mn (2.16-3.98), Fe (22.0-124), Co (18.7-91.7), $\mathrm{Ni}$ (9.68-19.2), Cu (16.8-233), Zn (17.4-28.2), and Cd (ND-1.56) in the stem samples. However, the levels of $\mathrm{Cr}$ and $\mathrm{Cd}$ in stem samples at one and two sample sites, respectively, and the levels of $\mathrm{Pb}$ in stem samples at all sample sites were below the method detection limit. This study showed that the leaf and stem of $R$. prinoides (Gesho) are good sources of essential minerals and virtually free from toxic metal $\mathrm{Cd}$ but not from $\mathrm{Pb}$ in the leaf.
\end{abstract}

KEY WORDS: Rhamnus prinoides, Gesho, Leaf, Stem, Minerals, Alcoholic beverages, Ethiopia

\section{INTRODUCTION}

Rhamnus prinoides (Amharic, Gesho) is in the family Rhamanceae [1]. It is a wide spread plant species in east and south African countries [2]. The only two Rhamnus species that occur in Africa are $R$. prinoides and $R$. staddo. $R$. prinoides is common in many parts of eastern and central Africa [3]. The plant is native to Ethiopia, Botswana, Eritrea, Lesotho, Namibia, South Africa, Swaziland, Uganda and it is exotic to Kenya [4]. It also occurs in Cameroon, Sudan, and Angola [5].

$R$. prinoides grows readily in most soils, but thrives in moist, humus-rich soils [4]. The natural habitat of $R$. prinoides is widespread and locally common at medium to high altitudes, along water courses, in riverside forest and at the margins of evergreen forests. The tree often appears quite black; or at times it glitters in the sun so conspicuously that it can be distinguished at a distance by this aspect alone. It shares this character with two other trees, Olea africana and Bequaertiodendron magalismontanum. It casts so deep a shade that it often prevents other growth around it $[1,4]$. It grows both as a cultivated plant and a natural component of mountain and revering forest in all parts of Ethiopia from 1400 to $3200 \mathrm{~m}$ [5-7].

Although it is quite common to find $R$. prinoides cultivations throughout the country, Tigray, North Shoa around Kara Kori and Sebeta, just west of Addis Ababa, are important centers of cultivation of $R$. prinoides [6]. In Tigray, $R$. prinoides is cultivated in the districts of south of Ahferom, Ganta Afeshaum and a small part of Werei Leke. $R$. prinoides is a valuable cash crop; leaves/twigs are harvested three times a year and sold year round. It is taken from the local area to the Enticho market, where it is sold to markets in western zone of Tigray, in Sheraro and Humera; and also to Adigrat in eastern zone of Tigray and Mekelle, the capital of

*Corresponding author. E-mail: bhagnan@chem.aau.edu.et, bscv2006@yahoo.com 
Tigray [7]. There is also a wide cultivation of R. prinoides in Amhara region, North Shoa. The important areas are in the districts: Antsekuyana-Gemza (particularly Majetye), Efratana-Gidim (around Karakori Kebele) and Gina Ager, nearly $72 \mathrm{~km}$ to the north east of Debre-Birhan town. Huge amount of $R$. prinoides is brought to Addis Ababa from all these areas. Specially, Ginager and Majetye are the main $R$. prinoides cultivation areas. Gedgamba, Migra and Ilamo kebeles in Sebeta district, Oromia region are also major $R$. prinoides cultivation areas.

$R$. prinoides has tremendous uses. It has been used for bitterness in the traditional brewing process for hundreds of years in East Africa. $R$. prinoides has potential use as a commercial hopping agent in the beer industry. An extract of this plant (a naphthalene glycoside, Geshoidin) is responsible for bitterness in local alcoholic beverages [8, 9]. Geshodin is a non-toxic substance found in bountiful amounts in the stem and leaves of $R$. prinoides [10]. In Ethiopia, the leaves and stems of this plant are used to impart the characteristic bitter flavor to domestically brewed beverages such as Tella and Tej and it was estimated that well over 5 million people consume these beverages everyday [11].

$R$. prinoides has also several traditional medicinal uses in Africa. A decoction of the root is taken as a blood purifier, to treat pneumonia, gonorrhea, rheumatism, stomach-ache, flu/cold, back pain, brucellosis, strength/nutrient supplement, and enhancing digestion [2, 12, 13]. The boiled soup of the root is used for the treatment of common cold, leaves are used for chest pain and leaves/stems are used for the treatment of tonsil in central Kenya [14]. It had been also studied that leaf paste mixed with butter as ointment is used for the treatment of Eczema (Amharic, chiffea) by people in Zegie Peninsula, northwestern Ethiopia [15].

Extract of $R$. prinoides is used for the inhibition of Alzheimer's disease. Sonicated aqueous extracts of A. nilotica and $R$. prinoides exhibited significant acetylcholinesterase inhibition [13]. Extract of the leaf and root bark of $R$. prinoides has been also used for malaria treatment either alone or in combination with chloroquine in Kenya. The extracts (leaves and root bark) used for malaria treatment in Kenya for in vivo anti-malarial activity in mice against a chloroquine resistant Plasmodium berghei NK65 showed high chemo suppression [16].

Living organisms (including plants, animals and microorganisms) store and transport metals so as to get appropriate concentration for later uses in physiological reactions as well as a means of protection against the toxic effects of the metals $[17,18]$. Mineral elements play critical role in building body tissue and regulating numerous physiological processes. They are thus essential constituents of enzymes and hormones; regulate a variety of physiological processes, and are required for the growth and maintenance of tissues and bones [19].

All trace elements are toxic if consumed at sufficiently high levels for long enough periods. The difference between toxic intakes and optimal intakes to meet physiological needs for essential trace elements is higher for some elements but is much smaller for others. Heavy metals (including $\mathrm{Cd}$ and $\mathrm{Pb}$ ) are stable elements (meaning they cannot be metabolized by the body) and bio-accumulative (passed up the food chain to humans). Most of the heavy metals have no function in the body and can be highly toxic. Nutritionally essential metals may cause adverse health effects at some levels below or beyond the level required for optimum nutrition [19].

Though $R$. prinoides has profound uses, its use has been limited to traditional alcoholic beverages and no attempt was made to make use of the plant parts for bitterness in commercial alcoholic beverages and chemotherapeutics. In addition, no report was found on the level of essential and toxic metals in this plant cultivated in Ethiopia or elsewhere. Hence, it was worthwhile investigating the level of essential and toxic metals in the leaf and stem of this plant. In this study, selected major, trace essential and toxic metal levels in the leaf and stem of $R$. prinoides in major cultivation areas of Ethiopia were assessed. It is believed that this study gives brief information on the level of metals in $R$. prinoides leaf and stem and inspire other 
researchers to explore the potential role of the leaves and stems of the plant in industrial alcoholic beverages.

The objectives of this study were: (i) to determine the level of essential metals $(\mathrm{Ca}, \mathrm{Mg}, \mathrm{Cr}$, $\mathrm{Mn}, \mathrm{Fe}, \mathrm{Co}, \mathrm{Ni}, \mathrm{Cu}$ and $\mathrm{Zn})$ and toxic $(\mathrm{Cd}$ and $\mathrm{Pb}$ ) metals in the leaf and stem of $R$. prinoides cultivated in Ethiopia, (ii) to correlate the levels of minerals in the leaf with that of stem of $R$. prinoides taken from the same sample site and (iii) to compare the levels of metals in $R$. prinoides leaf and stem in different sample sites.

\section{EXPERIMENTAL}

\section{Equipments and apparatus}

A drying oven (Digital Heat, J.P. Selecta, Spain), electronic blending device (Moulinex, France), mortar and pestle, electronic series balance (LA204, Switzerland) with precision of \pm $0.0001 \mathrm{~g}$, round bottom flasks $(100 \mathrm{~mL})$, reflux condensers, Kjeldahl digestion apparatus (Gallankamp, UK), borosilicate volumetric flasks (50 and $100 \mathrm{~mL}$ ), pipettes (Pyrex, USA), micropipettes (Dragonmed, 1-10 L, 100-1000 L, Shangai, China) and flame atomic absorption spectrophotometers (Buck Scientific Model 210VGP AAS, East Norwalk, USA) equipped with deuterium arc back ground correctors and hollow cathode lamps with air-acetylene flame were used in this study.

\section{Reagents and chemicals}

The reagents and chemicals used in this study were: $\mathrm{HNO}_{3}\left(69-72 \%, \mathrm{BDH}\right.$, England), $\mathrm{HClO}_{4}$ (70\%, Fine Chem, Mumbai, India), extra pure hydrogen peroxide $\left(30 \% \mathrm{H}_{2} \mathrm{O}_{2}\right.$, Scharlau, European Union), lanthanum nitrate hydrate (98\%, Aldrich, USA), stock standard solutions containing $1000 \mathrm{mg} / \mathrm{L}$ in $2 \% \mathrm{HNO}_{3}$ of the metals $\mathrm{Ca}, \mathrm{Mg}, \mathrm{Cr}, \mathrm{Mn}, \mathrm{Fe}, \mathrm{Co}, \mathrm{Ni}, \mathrm{Cu}, \mathrm{Zn}, \mathrm{Cd}$ and $\mathrm{Pb}$ (Buck Scientific Puro-Graphic, USA).

\section{Sample collection and transportation}

Sampling was done in a zigzag manner in an area coverage roughly two hectares and the approximate distance between two nearest $R$. prinoides plant from which leaf and stem samples were taken was roughly three meters. Fresh leaf and stem samples of $R$. prinoides were collected from nine farmlands of three regions of Ethiopia: Tigray, Amhara and Oromia. In Tigray, the samples were collected from eastern zone particularly, Gantafeshum district, Bizzet sub district, Kebelle Kesatyebirhan and from central zone, Ahferom district in particular areas: Adifeila, Edaga Arbi and Smiche Zala. In Amhara, the samples were collected from three major cultivation areas of North Shoa. These are Antsekuyanagemza district (particularly, Majetye), Efratanagidim (Karakori kebelle) and Gina Ager district (Tamo Kebelle) and in Oromia, the samples were collected from Sebeta district (Gedja Amba and Migra). The samples were collected in a three weeks interval. The leaves sampled were similar to those harvested by the cultivators. Very young, very old and yellow leaves were not sampled. The leaves sampled include the bottom, medium and the top part of the plant. The samples collected were placed and labeled in polyethylene plastic bags. Sampling of stem was similar to that of leaf sampling; however, the number of stems sampled was less than the number of leaves sampled. Both leaf and stem samples were then partially sun dried in the sample collection areas. Finally, the samples from each sample site were brought to laboratory for further pretreatment and analysis. The leaf samples were collected from 40 plants while the stem samples were taken from 30 
plants from each sample site. Approximate number of leaf samples and dry mass of stem samples are given in Table 1.

Table 1. Dry masses of stem and leaf samples and approximate number of leaf samples collected.

\begin{tabular}{|l|l|l|l|l|}
\hline Name of sample site & Region & $\begin{array}{l}\text { Mass of leaf samples } \\
\text { collected }(\mathrm{g})\end{array}$ & $\begin{array}{l}\text { Approximate } \\
\text { number of leaves }\end{array}$ & $\begin{array}{l}\text { Mass of stem samples } \\
\text { collected }(\mathrm{g})\end{array}$ \\
\hline Simchezala & Tigray & 136 & 985 & 69 \\
\hline Edaga-Arbi & Tigray & 258 & 1867 & 89 \\
\hline Adifeila & Tigray & 182 & 1316 & 69 \\
\hline Kesatyebirhan & Tigray & 149 & 1083 & 112 \\
\hline Majetye & Amhara & 176 & 1275 & 150 \\
\hline Karakori & Amhara & 132 & 954 & 86 \\
\hline Tamo & Amhara & 289 & 2096 & 175 \\
\hline Gedga Amba & Oromia & 120 & 866 & 51 \\
\hline Gedga Amba and Migra & Oromia & 250 & 1813 & 110 \\
\hline
\end{tabular}

\section{Sample preparation for elemental analysis}

Both the leaf and stem samples were further sun dried; leaves for three days and stems for two weeks. Stones and other wastes were removed from leaf and stem samples. The dried and cleaned stem samples were crushed into small pieces with mortar and pestle. Both leaf and stem samples were further dried in an oven at $80{ }^{\circ} \mathrm{C}$ for 24 hours. The dried leaf and stem samples were milled using electronic blender and sieved through $1 \mathrm{~mm}$ sieve. The powdered samples were stored in plastic bags until digestion and analysis.

Optimization of the digestion procedure for $R$. prinoides leaf and stem samples

The wet sample digestion was carried out using a reflux condenser for both leaf and stem samples. Four parameters: temperature, time, reagent volume and reagent ratio were optimized by varying one parameter and keeping the other parameters constant. Both leaf and stem sample were pre-digested for 30 min to minimize the vigorous reaction that may occur during digestion in the hot plate. The optimum conditions for $R$. prinoides leaf digestion were: temperature, 180 ${ }^{\circ} \mathrm{C}$; time, $2: 30 \mathrm{~h}$ and volume, $2.5+1+0.5 \mathrm{~mL}\left(\mathrm{HNO}_{3}+\mathrm{H}_{2} \mathrm{O}_{2}+\mathrm{HClO}_{4}\right)$ and the optimum conditions for $R$. prinoides stem digestion were: temperature, $210{ }^{\circ} \mathrm{C}$; time, $1: 50 \mathrm{~h}$ and volume, $3.5+1+$ $0.5 \mathrm{~mL}\left(\mathrm{HNO}_{3}+\mathrm{H}_{2} \mathrm{O}_{2}+\mathrm{HClO}_{4}\right)$.

Applying the optimized condition, $0.5 \mathrm{~g}$ of the dried and homogenized leaf and stem samples were added to a $100 \mathrm{~mL}$ round bottom flask. Then $4 \mathrm{~mL}$ mixture of $\mathrm{HNO}_{3}(69-72 \%)$, $\mathrm{H}_{2} \mathrm{O}_{2}(30 \%)$ and $\mathrm{HClO}_{4}(70 \%)$ to leaf sample and $5 \mathrm{~mL}$ to stem sample were added and the mixtures were pre-digested for $30 \mathrm{~min}$ at room temperature. After $30 \mathrm{~min}$ the mixtures were digested on a Kjeldahl digestion apparatus at the optimized condition. The digestion was carried out in triplicate for each bulk sample. Digestion of a reagent blank was also performed with the same procedure in parallel with the digestion of the samples keeping all digestion parameters the same. Six blanks were digested for both the leaf and stem samples. The digest was allowed to cool to room temperature for $30 \mathrm{~min}$. To the cooled solution $20 \mathrm{~mL}$ of de-ionized water was added and the solution was shacked to dissolve precipitates remained on the wall of the flask and to minimize dissolution of filter paper by residue. Lanthanum nitrate solution ( $1 \% \mathrm{w} / \mathrm{v})$ was added to the digested solution to eliminate the chemical interference of $\mathrm{Ca}$ and $\mathrm{Mg}$ ions and the solution was then filled to the mark $(50 \mathrm{~mL})$ with de-ionized water. The solutions were stored in the refrigerator until analysis. 
Analysis of R. prinoides leaf and stem samples for metal levels

Metal standard solutions for calibration were prepared from an intermediate standard solution containing $10 \mathrm{mg} / \mathrm{L}$ which was prepared from the atomic absorption spectroscopy standard stock solutions that contained $1000 \mathrm{mg} / \mathrm{L}$ for each of the metals. All the metals included in this study were analyzed with FAAS after the instrument was calibrated using four series of working standards. Three replicate determinations were carried out for each metal and the same analytical procedure was employed for the determination of the elements in blank solutions.

\section{Method performance evaluation}

Method validation is the process used to confirm that the analytical procedure employed for a specific test is suitable for its intended use. Results from method validation can be used to judge the quality, reliability and consistency of analytical results; it is an integral part of any good analytical practice. The parameters: accuracy, precision, specificity, limit of detection, limit of quantification, etc. are used for method validation [20]. In this study, precision of the results was evaluated by standard deviation of the results of the nine measurements, triplicate digestion and triplicate readings. The method detection limits for each metal were calculated from the standard deviation(s) of the replicate analysis of six blanks prepared by the optimized procedure: $\mathrm{MDL}=3 \times \mathrm{S}$ of blank. The concentrations of all the metals were above the method detection limit except for the concentrations of $\mathrm{Pb}$ in all stem samples, $\mathrm{Cd}$ in stem samples from two sample sites and $\mathrm{Cr}$ in stem sample from one sample site.

\section{Method validation}

In the present study, the optimized procedures were validated by determining metal concentration of a sample spiked with a known amount of each metal. Then, the percent recovery $(\% \mathrm{R})$ of the method was evaluated. Spiked samples were prepared by adding a small known quantity of metal standard solutions to three leaf samples of $R$. prinoides and three stem samples of $R$. prinoides and were analyzed by applying similar digestion procedure. The optimized procedure was also used to digest the blank $(n=6)$ samples. The procedures followed in the spiking of both the leaf and stem samples are described below.

\section{Spiking of leaf sample}

Three leaf samples, each weighing $0.5 \mathrm{~g}$ were transferred to round bottom flasks $(100 \mathrm{~mL})$. Known concentrations of the metal standard solutions were added to each of the three flasks using a micropipette: $32 \mu \mathrm{g} \mathrm{Ca}, 12 \mu \mathrm{g} \mathrm{Mg}, 0.058 \mu \mathrm{g} \mathrm{Cr}, 0.033 \mu \mathrm{g} \mathrm{Mn}, 0.53 \mu \mathrm{g} \mathrm{Fe}, 15 \mu \mathrm{g} \mathrm{Co}$, $0.075 \mu \mathrm{g} \mathrm{Ni}, 0.032 \mathrm{Cu}, 0.14 \mu \mathrm{g} \mathrm{Zn}, 0.012 \mu \mathrm{g} \mathrm{Cd}$, and $0.095 \mu \mathrm{g} \mathrm{Pb}$. The spiked samples were digested using the optimized procedure for the leaf sample and finally analyzed using FAAS to calculate the percent recoveries.

Spiking of stem sample

Three stem samples, each weighing $0.5 \mathrm{~g}$ were transferred to round bottom flasks $(100 \mathrm{~mL})$. Known concentrations of the metal standard solutions were added to each of the three flasks using a micropipette: $17 \mu \mathrm{g} \mathrm{Ca}, 11 \mu \mathrm{g} \mathrm{Mg}, 0.041 \mu \mathrm{g} \mathrm{Cr}, 0.018 \mu \mathrm{g} \mathrm{Mn}, 0.81 \mu \mathrm{g} \mathrm{Fe}, 0.35 \mu \mathrm{g} \mathrm{Co}$, $0.055 \mu \mathrm{g} \mathrm{Ni}, 0.50 \mathrm{Cu}, 0.12 \mu \mathrm{g} \mathrm{Zn}, 0.06 \mu \mathrm{g} \mathrm{Cd}$, and $0.053 \mu \mathrm{g} \mathrm{Pb}$. The spiked samples were digested using the optimized procedure for the stem sample and finally analyzed using FAAS to calculate the percent recoveries. 


\section{Statistical methods}

Linear regression analysis of calibration curve was used to calculate unknown concentration, sensitivity, correlation coefficients and standard deviation. Average concentration and standard deviations of triplicate measurements were reported for the samples. Variance in sampling and analysis were determined by F-test through one-way ANOVA. Student t-test was calculated to identify whether the means of the concentration between the two leaf samples and the two stem water samples vary significantly by Statistical Package for Social Science (SPSS statistic 15.0 Microsoft window) as well as excel work sheet (Microsoft Office Excel, 2007). The two statistical programs were also used to determine the levels of correlation of the metals within leaf, stem and between stem and leaf of $R$. prinoides.

\section{Figures of merit}

\section{RESULTS AND DISCUSSION}

The analytical wavelengths, linear range, correlation coefficients and correlation equations of the calibration curves for the determination of metals in the samples by FAAS are given in Table 2. The correlation coefficients of all the calibration curves were $>0.999$ and these correlation coefficients showed that there was very good correlation (relationship) between concentration and absorbance.

Detection limit of an analyte is the smallest quantity (concentration) of analyte which can be detected but not quantified at a given confidence level. Detection limit of certain method may vary greatly often with matrix and experimental procedures [21]. In this study method detection limit for each metal was estimated by digesting six analytical blanks with the optimized procedure for both the leaf and stem samples, respectively, of $R$. prinoides. Each blank solution was run with FAAS for the metal level in similar manner as the samples and standard deviations of the blanks' concentration were calculated. The method detection limit for the metal analytes is therefore here the concentration in the sample matrix at which analyte signal equals at least three times that of noise $\left(3 \delta_{\text {blank }}\right.$, where $\delta=$ standard deviation of the blanks, $n=6$ for leaf and $n$ $=6$ for stem samples (Table 2).

Table 2. Analytical wavelengths, detection limits, linear range, correlation coefficients, and correlation equations of the calibration curves for the determination of metals in $R$. Prinoides leaf and stem samples by FAAS.

\begin{tabular}{|c|c|c|c|c|c|c|}
\hline \multirow[t]{2}{*}{ Metal } & \multirow{2}{*}{$\begin{array}{c}\text { Wave } \\
\text { length } \\
(\mathrm{nm})\end{array}$} & \multicolumn{2}{|c|}{$\begin{array}{l}\text { Method detection limit } \\
(\mathrm{mg} / \mathrm{kg} \text { ) for }\end{array}$} & \multirow{2}{*}{$\begin{array}{l}\text { Linear range } \\
\qquad(\mathrm{mg} / \mathrm{L})\end{array}$} & \multirow{2}{*}{$\begin{array}{l}\text { Correlation } \\
\text { coefficient }\end{array}$} & \multirow[b]{2}{*}{ Calibration equation } \\
\hline & & $\begin{array}{c}\text { Leaf } \\
\text { sample }\end{array}$ & $\begin{array}{c}\text { Stem } \\
\text { samples }\end{array}$ & & & \\
\hline $\mathrm{Ca}$ & 422.7 & 0.06 & 0.1 & $0.5-4.0$ & 0.9998 & $\mathrm{Y}=0.00201 \mathrm{X}+8.41 \times 10^{-5}$ \\
\hline $\mathrm{Mg}$ & 285.2 & 0.1 & 0.2 & $0.25-2.0$ & 0.9998 & $Y=0.00595 X-1.57 \times 10^{-5}$ \\
\hline $\mathrm{Cr}$ & 357.9 & 0.05 & 0.05 & $0.5-3.0$ & 0.9997 & $Y=0.0122 X+3.22 \times 10^{-5}$ \\
\hline $\mathrm{Mn}$ & 279.5 & 0.02 & 0.02 & $0.25-2.0$ & 0.9997 & $\mathrm{Y}=0.0122 \mathrm{X}+3.22 \times 10^{-5}$ \\
\hline $\mathrm{Fe}$ & 248.3 & 0.3 & 0.3 & $0.5-3.0$ & 0.9994 & $\mathrm{Y}=0.00249 \mathrm{X}+2.40 \times 10^{-5}$ \\
\hline Co & 240.7 & 0.06 & 0.05 & $0.25-2.0$ & 0.9994 & $\mathrm{Y}=0.00249 \mathrm{X}+2.40 \times 10^{-5}$ \\
\hline $\mathrm{Ni}$ & 232.0 & 0.06 & 0.05 & $0.25-2.0$ & 0.9999 & $Y=0.00500 X+2.65 \times 10^{-5}$ \\
\hline $\mathrm{Cu}$ & 324.7 & 0.06 & 0.03 & $0.5-3.0$ & 0.9998 & $Y=0.00595 X-1.57 \times 10^{-4}$ \\
\hline $\mathrm{Zn}$ & 213.9 & 0.03 & 0.03 & $0.1-0.8$ & 0.9997 & $\mathrm{Y}=0.0122 \mathrm{X}+3.22 \times 10^{-4}$ \\
\hline $\mathrm{Cd}$ & 228.9 & 0.006 & 0.006 & $0.25-2.0$ & 0.9997 & $Y=0.0122 X+3.22 \times 10^{-4}$ \\
\hline $\mathrm{Pb}$ & 283.2 & 0.12 & 0.11 & $1.0-4.0$ & 0.9997 & $Y=0.0122 X+3.22 \times 10^{-4}$ \\
\hline
\end{tabular}

The method detection limits estimated for the leaf and stem samples were low enough to detect the presence of metals of interest at trace levels in both the leaf and stem samples of $R$. 
prinoides. The reproducibility of the analytical procedure was checked by carrying out a triplicate analysis and calculating the relative standard deviations for each metal. The \% RSD results did not differ by more than $10 \%$ of the mean which indicated that the analytical method used is precise and reliable.

In this study, the method was validated by the spiking experiment in which known quantities of the metals standard solution were added to three samples for leaf and stem samples. The spiked samples were then digested using the optimized procedure and calculated the percent recoveries. The obtained percentage recovery varied from 92 to $103 \%$ in the leaf samples and from 91 to $103 \%$ in the stem samples which were in the acceptable range (Table 3 and 4).

Table 3. Recovery test results for the optimized procedure of $R$. Prinoides leaf samples.

\begin{tabular}{|c|c|c|c|c|}
\hline Metal & $\begin{array}{c}\text { Concentration of metal in the } \\
\text { un-spiked sample }(\mu \mathrm{g} / \mathrm{g})\end{array}$ & $\begin{array}{c}\text { Amount } \\
\text { spiked }(\mu \mathrm{g})\end{array}$ & $\begin{array}{c}\text { Concentration of metal in } \\
\text { the spiked sample }(\mu \mathrm{g} / \mathrm{g})\end{array}$ & $\begin{array}{c}\text { Percent recovered } \\
(\%)\end{array}$ \\
\hline $\mathrm{Ca}$ & $125 \pm 5$ & 32 & $156 \pm 6$ & $97 \pm 4$ \\
\hline $\mathrm{Mg}$ & $51.7 \pm 2.5$ & 12 & $63.6 \pm 2.8$ & $99 \pm 5$ \\
\hline $\mathrm{Cr}$ & $0.22 \pm 0.01$ & 0.058 & $0.28 \pm 0.01$ & $103 \pm 8$ \\
\hline $\mathrm{Mn}$ & $0.14 \pm 0.01$ & 0.033 & $0.17 \pm 0.01$ & $103 \pm 4$ \\
\hline $\mathrm{Fe}$ & $2.16 \pm 0.15$ & 0.53 & $2.66 \pm 0.17$ & $94 \pm 6$ \\
\hline $\mathrm{Co}$ & $0.6 \pm 0.003$ & 0.15 & $0.74 \pm 0.003$ & $93 \pm 5$ \\
\hline $\mathrm{Ni}$ & $0.34 \pm 0.002$ & 0.075 & $0.41 \pm 0.002$ & $93 \pm 3$ \\
\hline $\mathrm{Cu}$ & $0.21 \pm 0.001$ & 0.14 & $0.24 \pm 0.001$ & $94 \pm 6$ \\
\hline $\mathrm{Zn}$ & $0.41 \pm 0.002$ & 0.012 & $0.54 \pm 0.002$ & $93 \pm 5$ \\
\hline $\mathrm{Cd}$ & $0.044 \pm 0.008$ & 0.095 & $0.055 \pm 0.009$ & $92 \pm 8$ \\
\hline $\mathrm{Pb}$ & $0.31 \pm 0.016$ & & & $95 \pm 0.019$ \\
\hline
\end{tabular}

Table 4. Recovery test for the optimized procedure of $R$. Prinoides stem samples.

\begin{tabular}{|c|c|c|c|c|}
\hline Metal & $\begin{array}{c}\text { Concentration of metal in } \\
\text { the un-spiked sample }(\mu \mathrm{g} / \mathrm{g})\end{array}$ & $\begin{array}{c}\text { Amount } \\
\text { spiked }(\mu \mathrm{g})\end{array}$ & $\begin{array}{c}\text { Concentration of metal in } \\
\text { the spiked sample }(\mu \mathrm{g} / \mathrm{g})\end{array}$ & $\begin{array}{c}\text { Percent recovered } \\
(\%)\end{array}$ \\
\hline $\mathrm{Ca}$ & $57.9 \pm 2.4$ & 17 & $74.6 \pm 2.6$ & $98 \pm 6$ \\
\hline $\mathrm{Mg}$ & $36.5 \pm 1.2$ & 11 & $47.8 \pm 1.4$ & $103 \pm 3$ \\
\hline $\mathrm{Cr}$ & $0.13 \pm 0.006$ & 0.041 & $0.17 \pm 0.007$ & $97 \pm 7$ \\
\hline $\mathrm{Mn}$ & $0.056 \pm 0.0005$ & 0.018 & $0.073 \pm 0.0006$ & $94 \pm 5$ \\
\hline $\mathrm{Fe}$ & $2.81 \pm 0.13$ & 0.81 & $3.64 \pm 0.14$ & $103 \pm 4$ \\
\hline $\mathrm{Co}$ & $1.24 \pm 0.07$ & 0.35 & $1.57 \pm 0.09$ & $94 \pm 6$ \\
\hline $\mathrm{Ni}$ & $0.19 \pm 0.007$ & 0.055 & $0.24 \pm 0.008$ & $91 \pm 5$ \\
\hline $\mathrm{Cu}$ & $2.18 \pm 0.12$ & 0.50 & $2.65 \pm 0.13$ & $94 \pm 8$ \\
\hline $\mathrm{Zn}$ & $0.41 \pm 0.008$ & 0.12 & $0.52 \pm 0.008$ & $92 \pm 3$ \\
\hline $\mathrm{Cd}$ & $0.025 \pm 0.0002$ & 0.06 & $0.084 \pm 0.0002$ & $98 \pm 6$ \\
\hline $\mathrm{Pb}$ & $0.17 \pm 0.008$ & 0.053 & $0.22 \pm 0.009$ & $93 \pm 7$ \\
\hline
\end{tabular}

Levels of metals in $R$. prinoides leaf and stem samples

The average concentrations of the metals (mean \pm SD) are given Tables 5 and 6 . In both leaf and stem samples, Ca was the most abundant and $\mathrm{Mg}$ was the second abundant. This is most likely that these elements are among the major elements required by plants. From the micro elements determined, Fe was the most abundant in leaf samples but there was irregularity in stem samples; copper content was higher in the stem samples from Gedga Amba, Gedgamba and migra, Gina Ager, Karakori and Majetye, where as Fe content was higher in the samples from Kesatyebirhan, Adifeila, and Edaga Arbi. 
As it is shown in Tables 5 and 6 , concentration of $\mathrm{Cu}$ in stem samples from Tigray was less than the other regions. Surprisingly, however, the concentration of $\mathrm{Cu}$ in leaf samples from Tigray was greater than in stem samples of the other regions; in addition, $\mathrm{Cu}$ concentration in leaf samples was higher than $\mathrm{Cu}$ concentration in stem samples of the corresponding sample sites in Tigray but it was the reverse in the other regions of Ethiopia.

Table 5. Average concentrations (mean $\pm \mathrm{SD}$ ) of the metals in $R$. prinoides leaf samples.

\begin{tabular}{|l|l|c|c|c|c|c|c|c|c|c|c|c|}
\hline \multirow{2}{*}{$\begin{array}{l}\text { Centre of } \\
\text { cultivation }\end{array}$} & \multirow{2}{*}{ Sample site } & \multicolumn{10}{|c|}{ Concentration of metals $(\mathrm{mg} / \mathrm{kg}) \pm \mathrm{SD}$} \\
\cline { 3 - 12 } & & $\mathrm{Ca}$ & $\mathrm{Mg}$ & $\mathrm{Cr}$ & $\mathrm{Mn}$ & $\mathrm{Fe}$ & $\mathrm{Co}$ & $\mathrm{Ni}$ & $\mathrm{Cu}$ & $\mathrm{Zn}$ & $\mathrm{Cd}$ & $\mathrm{Pb}$ \\
\hline Tigray & Simchezala & 22236 & 5428 & 5.08 & 17.9 & 47.9 & 30.0 & 16.8 & 32.2 & 13.5 & 1.44 & 17.1 \\
& & \pm 293 & \pm 127 & \pm 0.10 & \pm 0.3 & \pm 2.1 & \pm 0.5 & \pm 0.7 & \pm 1.6 & \pm 2.1 & \pm 0.12 & \pm 0.6 \\
\hline Tigray & Edaga-Arbi & 11546 & 3202 & 9.32 & 17.2 & 139 & 33.5 & 25.3 & 73.0 & 13.4 & 0.81 & 20.2 \\
& & \pm 132 & \pm 18 & \pm 0.06 & \pm 0.5 & \pm 3 & \pm 0.5 & \pm 0.3 & \pm 1.1 & \pm 1.3 & \pm 0.06 & \pm 0.7 \\
\hline Tigray & Adifeila & 6304 & 5017 & 16.1 & 11.5 & 133 & 22.2 & 14.1 & 26.8 & 27.9 & 0.94 & 21.6 \\
& & \pm 195 & \pm 90 & \pm 0.1 & \pm 0.3 & \pm 2 & \pm 0.3 & \pm 0.4 & \pm 0.7 & \pm 1.1 & \pm 0.05 & \pm 0.3 \\
\hline Tigray & Kesatyebirhan & 7234 & 4781 & 9.42 & 13.0 & 187 & 42.1 & 27.3 & 30.0 & 18.8 & 1.11 & 19.5 \\
& & \pm 175 & \pm 140 & \pm 0.15 & \pm 0.2 & \pm 6 & \pm 0.7 & \pm 1.0 & \pm 0.7 & \pm 0.7 & \pm 0.05 & \pm 1.1 \\
\hline North Shoa a & Majetye & 16394 & 5706 & 15.5 & 15.5 & 93.4 & 35.2 & 19.7 & 11.7 & 17.4 & 2.14 & 17.3 \\
& & \pm 347 & \pm 107 & \pm 0.4 & \pm 0.2 & \pm 2.1 & \pm 1.0 & \pm 0.9 & \pm 0.5 & \pm 0.7 & \pm 0.12 & \pm 1.0 \\
\hline North Shoa a & Karakori & 12432 & 4622 & 15.8 & 10.1 & 88.0 & 36.2 & 25.6 & 10.3 & 18.3 & 3.10 & 20.3 \\
& & \pm 398 & \pm 114 & \pm 0.7 & \pm 0.3 & \pm 4.3 & \pm 0.9 & \pm 0.6 & \pm 0.3 & \pm 0.6 & \pm 0.11 & \pm 1.2 \\
\hline North Shoa & Tamo & 7202 & 5347 & 18.7 & 8.12 & 87.9 & 29.6 & 18.8 & 11.2 & 27.9 & 2.11 & 25.0 \\
& & \pm 80 & \pm 99.7 & \pm 0.3 & \pm 0.22 & \pm 2.1 & \pm 1.3 & \pm 0.7 & \pm 0.3 & \pm 1.4 & \pm 0.1 & \pm 1.40 \\
\hline Oromia, & Gedga Amba & 12994 & 3361 & 14.9 & 14.9 & 88.4 & 30.8 & 26.4 & 19.4 & 12.2 & 1.78 & 18.4 \\
Sebeta & & \pm 131 & \pm 83 & \pm 0.4 & \pm 0.6 & \pm 3.2 & \pm 1.5 & \pm 0.3 & \pm 0.5 & \pm 0.3 & \pm 0.09 & \pm 1.33 \\
\hline Oromia, & Gedga Amba & 11358 & 4121 & 20.6 & 12.1 & 136 & 34.9 & 12.8 & 6.50 & 43.0 & 2.18 & 18.8 \\
Sebeta & and Migra & \pm 213 & \pm 93 & \pm 0.3 & \pm 0.3 & \pm 4 & \pm 0.7 & \pm 0.4 & \pm 0.4 & \pm 1.6 & \pm 0.08 & \pm 1.10 \\
\hline
\end{tabular}

Table 6. Average concentrations (mean \pm SD) of the metals in R. prinoides stem samples.

\begin{tabular}{|c|c|c|c|c|c|c|c|c|c|c|c|c|}
\hline \multirow{2}{*}{$\begin{array}{l}\text { Centere of } \\
\text { cultivation }\end{array}$} & \multirow[b]{2}{*}{ Sample site } & \multicolumn{11}{|c|}{ Concentration of metals $(\mathrm{mg} / \mathrm{kg}) \pm \mathrm{SD}$} \\
\hline & & $\mathrm{Ca}$ & $\mathrm{Ag}$ & $\mathrm{Cr}$ & $\mathrm{Mn}$ & $\mathrm{Fe}$ & $\mathrm{Co}$ & $\mathrm{Ni}$ & $\mathrm{Cu}$ & $\mathrm{Zn}$ & $\mathrm{Cd}$ & $\mathrm{Pb}$ \\
\hline Tigra & Sime & $\begin{array}{r}510 \\
10 \\
\end{array}$ & $\begin{array}{c}3123 \pm \\
85 \\
\end{array}$ & $\mathrm{ND}$ & & $\begin{array}{c}22.0 \pm \\
0.7 \\
\end{array}$ & $\begin{array}{c}18.7 \pm \\
0.4 \\
\end{array}$ & 0.8 & \begin{tabular}{|c|}
$23.4 \pm$ \\
1.4 \\
\end{tabular} & $\begin{array}{c}21.5 \pm \\
0.8 \\
\end{array}$ & $\begin{array}{c}1.26 \pm \\
0.10\end{array}$ & ND \\
\hline Гig & & & $\begin{array}{c}3440 \pm \\
98\end{array}$ & \begin{tabular}{|l|}
$9.51 \pm$ \\
0.25 \\
\end{tabular} & & \begin{tabular}{|c|c}
$105 \pm$ \\
7
\end{tabular} & & $\begin{array}{c}19.2 \pm \\
0.9\end{array}$ & \begin{tabular}{|c|}
$16.8 \pm$ \\
0.5 \\
\end{tabular} & $\begin{array}{c}17.9 \pm \\
1.0 \\
\end{array}$ & & $D$ \\
\hline igra & & $\begin{array}{c}4312 \pm \\
41\end{array}$ & $\begin{array}{c}5102 \pm \\
89 \\
\end{array}$ & \begin{tabular}{|c|}
$7.44 \pm$ \\
0.14 \\
\end{tabular} & & $115 \pm 6$ & & $\begin{array}{c}14.7 \pm \\
0.4 \\
\end{array}$ & $\begin{array}{c}28.2 \pm \\
1.3 \\
\end{array}$ & $\begin{array}{c}24.3 \pm \\
1.7 \\
\end{array}$ & $\begin{array}{c}1.00 \pm \\
0.04 \\
\end{array}$ & D \\
\hline Tigray & $\mathrm{K}$ & $\begin{array}{c}4272 \pm \\
122 \\
\end{array}$ & \begin{tabular}{|c|}
$5528 \pm$ \\
128 \\
\end{tabular} & \begin{tabular}{|c|}
$6.58 \pm$ \\
0.21 \\
\end{tabular} & & $\begin{array}{c}124 \pm \\
5 \\
\end{array}$ & 1 & $\begin{array}{c}15.6 \pm \\
0.3 \\
\end{array}$ & \begin{tabular}{|c|}
$18.6 \pm$ \\
0.9 \\
\end{tabular} & \begin{tabular}{|c|}
$19.1 \pm$ \\
1.0 \\
\end{tabular} & ND & ND \\
\hline a & Maje & $\begin{array}{c}4358 \pm \\
63\end{array}$ & $\begin{array}{c}5223 \pm \\
99\end{array}$ & \begin{tabular}{|c|}
$16.3 \pm$ \\
0.2 \\
\end{tabular} & $\begin{array}{c}2.33 \pm \\
0.13 \\
\end{array}$ & \begin{tabular}{|c|}
$40.0 \pm$ \\
2.1 \\
\end{tabular} & $\begin{array}{r}71 \\
3 \\
\end{array}$ & $\begin{array}{c}9.68 \pm \\
0.50 \\
\end{array}$ & $170 \pm 1$ & $\begin{array}{c}28.2 \pm \\
0.9 \\
\end{array}$ & $\begin{array}{l}1.16 \pm \\
0.06\end{array}$ & ND \\
\hline $\mathrm{a}$ & & $\begin{array}{c}5675 \pm \\
133 \\
\end{array}$ & $\begin{array}{c}3417 \pm \\
41 \\
\end{array}$ & \begin{tabular}{|c|}
$6.83 \pm$ \\
0.16 \\
\end{tabular} & \begin{tabular}{|c}
$2.16 \pm$ \\
0.13 \\
\end{tabular} & $\begin{array}{c}71.4 \pm \\
5.4 \\
\end{array}$ & $\begin{array}{c}91.7 \pm \\
3.8 \\
\end{array}$ & $\begin{array}{c}11.5 \pm \\
0.4 \\
\end{array}$ & $210 \pm 2$ & $\begin{array}{c}19.1 \pm \\
0.7 \\
\end{array}$ & $\begin{array}{c}1.56 \pm \\
0.10\end{array}$ & ND \\
\hline$\overline{\mathrm{ba}}$ & $\mathrm{T}$ & $\begin{array}{c}3601 \pm \\
85\end{array}$ & $\begin{array}{c}2667 \pm \\
58\end{array}$ & \begin{tabular}{|c|}
$7.65 \pm$ \\
0.21 \\
\end{tabular} & $\begin{array}{c}2.23 \pm \\
0.06\end{array}$ & $\begin{array}{c}45.3 \pm \\
1.9 \\
\end{array}$ & $\begin{array}{c}45.4 \pm \\
1.4 \\
\end{array}$ & $\begin{array}{c}11.4 \pm \\
0.6\end{array}$ & \begin{tabular}{|c|}
$126 \pm$ \\
5 \\
\end{tabular} & \begin{tabular}{|c|}
$18.2 \pm$ \\
0.6 \\
\end{tabular} & $\begin{array}{c}1.21 \pm \\
0.08\end{array}$ & ND \\
\hline brol & G & $\begin{array}{c}5552 \pm \\
157\end{array}$ & $\begin{array}{c}2642 \pm \\
55\end{array}$ & \begin{tabular}{|c|}
$5.42 \pm$ \\
0.17 \\
\end{tabular} & $\begin{array}{c}2.28 \pm \\
0.16\end{array}$ & \begin{tabular}{|c|}
$47.4 \pm$ \\
2.7 \\
\end{tabular} & $\begin{array}{c}45.3 \pm \\
2.8 \\
\end{array}$ & $\begin{array}{c}13.6 \pm \\
0.8 \\
\end{array}$ & \begin{tabular}{|c|}
$233 \pm$ \\
2 \\
\end{tabular} & $\begin{array}{c}24.4 \pm \\
0.7\end{array}$ & $\begin{array}{c}1.14 \pm \\
0.09\end{array}$ & ND \\
\hline & Ge & $\begin{array}{c}4677 \pm \\
115\end{array}$ & $\begin{array}{c}2635 \pm \\
77 \\
\end{array}$ & $\begin{array}{c}17.4 \pm \\
0.2\end{array}$ & $\begin{array}{c}2.36 \pm \\
0.13\end{array}$ & $\begin{array}{c}120 \pm \\
7\end{array}$ & $\begin{array}{c}41.0 \pm \\
1.5\end{array}$ & $\begin{array}{c}13.1 \pm \\
0.8\end{array}$ & $\begin{array}{c}182 \pm \\
11\end{array}$ & $\begin{array}{c}17.4 \pm \\
0.8 \\
\end{array}$ & ND & ND \\
\hline
\end{tabular}

ND indicates the level was less than method detection limit. 
Similarly, the concentration of Mg in leaf samples from Tigray (Edaga Arbi, Adifeila and Kesatyebirhan) was less than in stem samples but it was higher in leaf samples than in stem samples from the rest of the sample sites. Such irregularities cannot be certainly explained, nevertheless, it might be attributed to either effect of age of plant on mineral accumulation; for example, in Tigray, the people do not harvest the stem of the plant unlike the people of other regions. Thus, stem samples collected from Tigray were older than the stem samples collected from Amhara and Oromia and this in turn may result in a difference in the accumulation of $\mathrm{Cu}$ in the different sample sites or to a smaller extent it might be due to a difference in collection time. The concentration of a metal may differ even in short duration for the samples collected from Tigray were a week before those from Amhara and two weeks before those collected from Oromia.

In case of $\mathrm{Mg}$, the smaller concentration in leaf samples than stem samples collected from Tigray could be attributed to a difference in sampling time ling; these samples were collected early in the morning and hence, they might not get sufficient sun light which in turn results in little rate of photosynthesis and hence less uptake of $\mathrm{Mg}$ by leaf.

Among the micro nutrients the concentration of $\mathrm{Cr}$ and $\mathrm{Mn}$ was the least in leaf samples in some sample sites and $\mathrm{Mn}$ in another sample sites but the concentration of $\mathrm{Mn}$ in stem was the least in all the sample sites. This is probably either the metals are not bioavailable or the intake of these metals by the plant may be small.

Among the two toxic elements, concentration of $\mathrm{Pb}$ was higher in the leaf samples from all the sample sites. Whereas, concentrations of $\mathrm{Pb}$ in stem samples from all the sample sites were below the method detection limit. Such marked differences in concentration of $\mathrm{Pb}$ in leaf and stem might be attributed to the difference in the degree of exposure to contamination between leaf and stem or uptake of $\mathrm{Pb}$ (II) by leaves may be higher than stems.

Generally, the concentrations of the metals were higher in $R$. prinoides leaf than in stem samples. Such a difference is probably attributed to a difference in metal uptake or the exposure to contamination for instance; leaves hold more dust and other particles than stems.

The concentration of $\mathrm{Cu}$ and $\mathrm{Co}$ in some sample sites was higher than the usual plant take up $(1-25 \mathrm{mg} / \mathrm{kg})$. This is most likely attributed to the contamination of the plant material by the soil as the samples were taken from a farm land and the samples were not washed by de-ionized water. The unusual high concentration of these metals in some sample sites might also be due to the nature of the soil.

The relatively high concentration of $\mathrm{Pb}$ in leaf samples from some sample sites is most likely attributed to contamination from soil/dust, from transport emissions or the soil from which the samples were taken might be lead rich or it might be from fertilizers.

In summary, the relatively low concentration of $\mathrm{Mg}$ in leaf sample at Edaga Arbi, the very small concentration of $\mathrm{Ca}$ in leaf sample at Adifeila and Kesatyebirhan, and the extremely high concentration of $\mathrm{Ca}$ in leaf samples at Simichezala, the extremely small concentration of $\mathrm{Fe}$ in both leaf and stem samples at Simichezala and high concentration at Kesatyebirhan, the marked difference of $\mathrm{Cu}$ concentration between leaf and stem samples at Edaga Arbi, the relatively small concentration of $\mathrm{Mg}$ in stem samples at the sample sites Tamo, Gedga Amba, Gedga Amba and Migra are most likely because of a variation in at least one of the following: bioavailability, physical property of the soil, soil $\mathrm{pH}$, competition of uptake of the metals by the plant, age of the leaf or the stem, season of sample collection, soil fertility, acidic-alkaline and reductive-oxidative conditions, content of organic matter and mineral content of the soil [2225]. 
Distribution pattern of the metals in $R$. prinoides leaf and stem samples

In leaf samples, distribution of $\mathrm{Ca}$ in all the samples was the highest $(6304-22236 \mathrm{mg} / \mathrm{kg}$ ) and $\mathrm{Mg}$ was the second highest (3202-4622 mg/kg). Among the micro nutrients, Fe content was the highest $(47.9-187 \mathrm{mg} / \mathrm{kg}$ ), followed by $\mathrm{Cu}$ and $\mathrm{Zn}$ which were the second highest: $6.5-73$, $12.2-43$, respectively and this might be attributed to the higher requirement of these metals among the trace elements. Co $(22.2-42.1 \mathrm{mg} / \mathrm{kg}), \mathrm{Ni}(12.8-27.3 \mathrm{mg} / \mathrm{kg}), \mathrm{Cr}(5.08-20.6 \mathrm{mg} / \mathrm{kg})$, and $\mathrm{Mn}(8.12-17.9 \mathrm{mg} / \mathrm{kg})$ were present at relatively low levels. The toxic metal Cd (0.81-3.1 $\mathrm{mg} / \mathrm{kg}$ ) was present at low levels but $\mathrm{Pb}(17.1-25 \mathrm{mg} / \mathrm{kg}$ ) was present in appreciable levels. In general, the concentration of the metals in $R$. prinoides leaf samples was in the order: $\mathrm{Ca}>\mathrm{Mg}$ $>\mathrm{Fe}>\mathrm{Cu} \approx \mathrm{Zn} \approx \mathrm{Co}>\mathrm{Ni}>\mathrm{Pb}>(\mathrm{Mn}, \mathrm{Cr})>\mathrm{Cd}$.

In stem samples, the level of $\mathrm{Ca}(3601-5675 \mathrm{mg} / \mathrm{kg})$ was the highest in most of the samples except in some samples in which $\mathrm{Mg}(26-35-5528 \mathrm{mg} / \mathrm{kg}$ ) was the most abundant in stem samples. Among the micronutrients, Fe (40-124 mg/kg) content was the highest in some samples and $\mathrm{Cu}(16.8-233 \mathrm{mg} / \mathrm{kg})$ in other samples followed by Co $(18.7-91.7 \mathrm{mg} / \mathrm{kg}), \mathrm{Zn}$ $(17.4-28.2 \mathrm{mg} / \mathrm{kg}$ ) and $\mathrm{Ni}(9.68-19.2 \mathrm{mg} / \mathrm{kg})$. The levels of $\mathrm{Cr}(\mathrm{ND}-17.4 \mathrm{mg} / \mathrm{kg})$ and $\mathrm{Mn}$ $(2.16-3.98 \mathrm{mg} / \mathrm{kg}$ ) were the smallest. The toxic metal Cd (ND-1.56 mg/kg) was present at very low levels and $\mathrm{Pb}$ was not detected in all the samples. In general, the concentration of the metals in $\mathrm{R}$. prinoides stem samples was in the order: $\mathrm{Ca}>\mathrm{Mg}>\mathrm{Fe} \approx \mathrm{Cu}>\mathrm{Co}>\mathrm{Zn}>\mathrm{Ni}>\mathrm{Cr}>\mathrm{Mn}>$ $\mathrm{Cd}>\mathrm{Pb}$.

\section{Comparison of metal levels between leaf and stem of $R$. prinoides}

It is reported in many literatures that accumulation of elements in plants is affected by the soils' mineral content, the medium of the soil and differences in different parts of the plant. In this study the levels of metals in leaf and stem sampled from the same sample site and from the same plants were compared.

In general, as it is shown in Tables 5 and 6, the levels of the metals were higher in leaf samples than in stem samples. Level of macro elements in leaf samples was higher than in stem except at some sample sites where level of $\mathrm{Mg}$ was slightly higher in stem samples. $\mathrm{Mn}, \mathrm{Fe}, \mathrm{Ni}$ and $\mathrm{Cr}$ were higher in leaf samples in most of the sample sites than in stem samples. The level of Co was higher in stem samples in most of the sample sites whereas the content of $\mathrm{Cu}$ and $\mathrm{Zn}$ was not regular. Cd was higher in leaf samples except two sample sites. Among the toxic metals, Cd was present at higher levels in leaf than in stem but at low levels while $\mathrm{Pb}$ was present at appreciable levels in the leaf samples but was not detected in all the stem samples.

At last, it is interesting to note that the levels of the metals obtained were from complete digestion of the leaf and stem sample but in the actual human consumption of the leaf and stem the powdered samples are added to the local alcoholic beverages, and therefore a complete digestion is not expected from the fermentation/metabolism and hence the metal content in the beverage bio-available to human may be less than the amount obtained from the analysis.

\section{Statistical analysis}

\section{Analysis of variance}

Whether the difference in the means of more than two samples is real or the result of random error was tested by analysis of variance (ANOVA). The statistical tool F test was applied for the analysis of variance. To detect whether the difference in means of the concentration of the samples is significant at $95 \%$ confidence level, the one-way ANOVA, was applied. The results indicated that there was a significance difference between the means of all the metals both in stem and leaf samples collected from nine sample sites. This implies that the variation in metal 
concentration among sample sites was not due to the random errors introduced from sample preparation to analysis rather it was real. The factors that contributed to such variation are likely to be a difference in the physical and chemical characteristics of the soil, soil enrichment, age of the leaf and/or stem and mineral content of the soil.

\section{Pearson correlation}

Pearson's correlation [26] of the metals within leaf, stem and between stem and leaf of $R$. prinoides are shown in Tables 7, 8 and 9.

Table 7. Correlation matrices for metals (mean level from all sample sites) in $R$. prinoides leaf samples $(\mathrm{n}=9, \mathrm{p}=0.05)$.

\begin{tabular}{|l|l|l|l|l|l|l|l|l|l|l|l|}
\hline & $\mathrm{Mg}$ & $\mathrm{Ca}$ & $\mathrm{Cd}$ & $\mathrm{Cr}$ & $\mathrm{Mn}$ & $\mathrm{Fe}$ & $\mathrm{Co}$ & $\mathrm{Ni}$ & $\mathrm{Cu}$ & $\mathrm{Zn}$ & $\mathrm{Pb}$ \\
\hline $\mathrm{Mg}$ & 1 & & & & & & & & & & \\
\hline $\mathrm{Ca}$ & 0.173 & 1 & & & & & & & & & \\
\hline $\mathrm{Cd}$ & 0.208 & 0.176 & 1 & & & & & & & & \\
\hline $\mathrm{Cr}$ & 0.004 & -0.486 & 0.544 & 1 & & & & & & & \\
\hline $\mathrm{Mn}$ & -0.230 & 0.700 & -0.479 & -0.728 & 1 & & & & & & \\
\hline $\mathrm{Fe}$ & -0.305 & -0.699 & -0.452 & 0.060 & -0.144 & 1 & & & & & \\
\hline $\mathrm{Co}$ & -0.107 & 0.050 & 0.248 & -0.166 & 0.079 & 0.398 & 1 & & & & \\
\hline $\mathrm{Ni}$ & -0.426 & -0.081 & 0.010 & -0.358 & 0.141 & 0.193 & 0.563 & 1 & & & \\
\hline $\mathrm{Cu}$ & -0.472 & 0.031 & -0.750 & -0.671 & 0.596 & 0.277 & -0.028 & 0.326 & 1 & & \\
\hline $\mathrm{Zn}$ & 0.116 & -0.435 & 0.204 & 0.721 & -0.582 & 0.293 & -0.122 & -0.706 & -0.479 & 1 & \\
\hline $\mathrm{Pb}$ & 0.072 & -0.744 & 0.021 & 0.424 & -0.772 & 0.147 & -0.320 & -0.060 & -0.045 & 0.331 & 1 \\
\hline
\end{tabular}

From Table 7, it can be depicted that there is a relatively high positive correlation: $\mathrm{Ca}$ with $\mathrm{Mn}$ and $\mathrm{Zn}$ with $\mathrm{Cr}, \mathrm{Cr}$ with $\mathrm{Cd}$ and $\mathrm{Ni}$ with $\mathrm{Co}$. $\mathrm{Cu}$ with $\mathrm{Ni}$, Co with $\mathrm{Fe}$ and $\mathrm{Pb}$ with $\mathrm{Zn}$ have weak positive correlation. $\mathrm{Pb}$ with $\mathrm{Ca}, \mathrm{Cu}$ with $\mathrm{Cd}$ and $\mathrm{Pb}$ with $\mathrm{Mn}$ have strong negative correlation. Fe with $\mathrm{Ca}, \mathrm{Mn}$ with $\mathrm{Cr}, \mathrm{Cu}$ with $\mathrm{Cr}, \mathrm{Zn}$ with $\mathrm{Mn}$ and $\mathrm{Zn}$ with Ni have a moderate negative correlation. $\mathrm{Cr}$ with $\mathrm{Ca}, \mathrm{Zn}$ with $\mathrm{Ca}, \mathrm{Cd}$ with $\mathrm{Mn}, \mathrm{Fe}$ with $\mathrm{Cd}$, $\mathrm{Ni}$ with $\mathrm{Cr}, \mathrm{Zn}$ with $\mathrm{Cu}$, and $\mathrm{Pb}$ with $\mathrm{Co}$ have a weak negative correlation. All the other correlations are poor. The high positive correlations may indicate uptake of the metal by the leaf of this plant facilitates the other, they have the same anthropogenic sources or they have similar function in the leaf of this plant. The high negative correlation on the other hand may indicate a competition in the uptake of these metals by the leaf. While those that have small positive or negative correlations indicate that they do not affect each other.

Table 8. Correlation matrices for metals (mean level from all sample sites) in $R$. prinoides stem samples $(\mathrm{n}=9, \mathrm{p}=0.05)$.

\begin{tabular}{|l|l|l|l|l|l|l|l|l|l|l|}
\hline & $\mathrm{Mg}$ & $\mathrm{Ca}$ & $\mathrm{Cd}$ & $\mathrm{Cr}$ & $\mathrm{Mn}$ & $\mathrm{Fe}$ & $\mathrm{Co}$ & $\mathrm{Ni}$ & $\mathrm{Cu}$ & $\mathrm{Zn}$ \\
\hline $\mathrm{Mg}$ & 1 & & & & & & & & & \\
\hline $\mathrm{Ca}$ & -0.310 & 1 & & & & & & & & \\
\hline $\mathrm{Cd}$ & -0.387 & 0.500 & 1 & & & & & & & \\
\hline $\mathrm{Cr}$ & 0.085 & -0.268 & -0.169 & 1 & & & & & & \\
\hline $\mathrm{Mn}$ & 0.618 & -0.405 & -0.469 & -0.155 & 1 & & & & & \\
\hline $\mathrm{Fe}$ & 0.336 & -0.240 & -0.184 & 0.229 & 0.740 & 1 & & & & \\
\hline $\mathrm{Co}$ & 0.353 & 0.234 & 0.359 & 0.146 & -0.209 & 0.011 & 1 & & & \\
\hline $\mathrm{Ni}$ & -0.030 & -0.006 & -0.136 & -0.395 & 0.623 & 0.342 & -0.751 & 1 & & \\
\hline $\mathrm{Cu}$ & -0.427 & 0.478 & 0.345 & 0.313 & 0.313 & -0.316 & 0.539 & -0.743 & 1 & \\
\hline $\mathrm{Zn}$ & 0.455 & 0.130 & -0.534 & 0.098 & -0.123 & -0.421 & 0.301 & -0.367 & 0.186 & 1 \\
\hline
\end{tabular}

Bull. Chem. Soc. Ethiop. 2012, 26(3) 
From Table 8 , it can be observed that $\mathrm{Mn}$ with $\mathrm{Mg}, \mathrm{Fe}$ and $\mathrm{Ni}$ and, $\mathrm{Co}$ with $\mathrm{Cu}$ have moderate positive correlation and $\mathrm{Mn}$ has relatively high positive correlation with $\mathrm{Fe}$. Mg with ( $\mathrm{Fe}, \mathrm{Co}$, and $\mathrm{Zn}$ ), Cd with (Ca, Co and $\mathrm{Cu}$ ), $\mathrm{Ni}$ with $\mathrm{Fe}$, Co with $\mathrm{Zn}$ and $\mathrm{Cu}$ with $(\mathrm{Ca}, \mathrm{Cr}$ and $\mathrm{Mn}$ ) have weak positive correlation. Co with $\mathrm{Ni}$ has strong negative correlation. $\mathrm{Cu}$ with $\mathrm{Ni}$ and $\mathrm{Zn}$ with $\mathrm{Cd}$ have moderate negative correlation. $\mathrm{Mg}$ with $(\mathrm{Ca}, \mathrm{Cd}$ and $\mathrm{Cu}), \mathrm{Ca}$ with $(\mathrm{Cr}$ and $\mathrm{Mn}$ ), Cd with $\mathrm{Mn}$, Ni with ( $\mathrm{Cr}$ and $\mathrm{Zn}$ ), Fe with ( $\mathrm{Cu}$ and $\mathrm{Zn}$ ) and $\mathrm{Ni}$ with $\mathrm{Zn}$ have weak negative correlation. The rest combinations have poor correlation. The reasons for the moderate and strong positive or negative correlation are associated with the factors mentioned above.

Table 9. Pearson correlation coefficient for metals (mean level from all sample sites) in $R$. prinoides leaf with stem sample $(\mathrm{n}=9, \mathrm{p}=0.05)$.

\begin{tabular}{|l|l|l|l|l|l|l|l|l|l|l|}
\hline Metal & $\mathrm{Mg}$ & $\mathrm{Ca}$ & $\mathrm{Cd}$ & $\mathrm{Cr}$ & $\mathrm{Mn}$ & $\mathrm{Fe}$ & $\mathrm{Co}$ & $\mathrm{Ni}$ & $\mathrm{Cu}$ & $\mathrm{Zn}$ \\
\hline $\mathrm{R}$ & 0.412 & 0.500 & 0.710 & 0.530 & 0.130 & 0.913 & 0.176 & 0.158 & -0.691 & -0.346 \\
\hline
\end{tabular}

As it is shown in Table 9, most of the metals except $\mathrm{Cu}$ and $\mathrm{Zn}$ have positive correlation between leaf and stem samples which indicate that similar factors affect the accumulation of these metals.

Comparison of the metal content in $R$. prinoides leaf sample with leaves of other medicinal plants

Comparison of levels of metals in $R$. prinoides leaves with other medicinal plants reported in literature is summarized in Table 10. The results of present study are in good agreement with the most of reported values for all the studied metals except Mn and Fe. The levels of $\mathrm{Mn}$ and $\mathrm{Fe}$ in the leaves of $R$. prinoides are lower than in the leaves of most of the other medicinal plants (Table 10).

Table 10A. Comparison of $\mathrm{Ca}, \mathrm{Mg}, \mathrm{Mn}, \mathrm{Fe}, \mathrm{Zn}$ concentration $(\mu \mathrm{g} / \mathrm{g})$ in $R$. prinoides leaves with other medicinal plant leaves.

\begin{tabular}{|c|c|c|c|c|c|c|c|}
\hline \multirow{2}{*}{ Medicinal plant } & \multirow{2}{*}{ Origin } & \multicolumn{6}{|c|}{ Concentration $(\mu \mathrm{g} / \mathrm{g})$ of metals in medicinal plants } \\
\hline & & $\mathrm{Ca}$ & $\mathrm{Mg}$ & $\mathrm{Mn}$ & $\mathrm{Fe}$ & $\mathrm{Zn}$ & Ref. \\
\hline $\begin{array}{l}\text { Taraxacum officinale } \\
\text { Weber }\end{array}$ & Spain & 29247 & 4461 & 101 & 853 & 68 & 27 \\
\hline Eucalyptus globulus Labill & Spain & 18621 & 1616 & 2134 & 89 & 23 & 27 \\
\hline Plantago major L. & Bulgaria & 48022 & 6405 & 46 & 373 & 56 & 27 \\
\hline Mentha piperita $\mathrm{L}$. & Bulgaria & 21131 & 5483 & 116 & 376 & 45 & 27 \\
\hline Matricaria chamomilla $\mathrm{L}$. & Egypt & 926 & 2642 & 76 & 701 & 49 & 27 \\
\hline Calotropis procera Ait. & Nigeria & 18900 & - & 231.5 & 1871.5 & 71.7 & 28 \\
\hline Acalypha wilkensiana & Nigeria & 28400 & - & 44.4 & 760.1 & 75.3 & 28 \\
\hline Euphorbia hirta Linn. & Nigeria & 8120 & - & 52 & 535.7 & 191.1 & 28 \\
\hline Pelargonium graveolens L. & Egypt & - & - & 26.4 & 516 & 12.1 & 29 \\
\hline Marjorana hortensis L. & Egypt & - & - & 28 & 671 & 10.59 & 29 \\
\hline Gynostemma pentaphyllum & Thailand & $5583-34070$ & $1756-7739$ & $43.42-259.4$ & $125.5-2321$ & $25.43-61.95$ & 30 \\
\hline Camellia sinensis & Thailand & $1384-6550$ & $783.6-2549$ & 229.4-1512 & $20.91-318.3$ & $10.13-55.40$ & 30 \\
\hline Morus alba & Thailand & $15286-25182$ & $3078-5188$ & 75.27-352.7 & $89.46-408.2$ & 19.16-34.42 & 30 \\
\hline Catha edulis Forsk & Ethiopia & $1,038-2,173$ & $478-812$ & $6.98-8.66$ & $53.95-82.83$ & $5.18-9.40$ & 31 \\
\hline $\begin{array}{l}\text { Thymus schimperi and } \\
\text { Thymus vulgaris }\end{array}$ & Ethiopia & $1239-2517$ & $1524-1786$ & $37.7-114$ & $728-2517$ & $8.7-52$ & 32 \\
\hline Croton macrostachyus & Ethiopia & $1201-7040$ & 271-2961 & $157-420$ & $167-581$ & $20-61$ & 33 \\
\hline R. prinoides & Ethiopia & $6304-22236$ & $3202-5706$ & $8.12-17.9$ & $47.9-187$ & $12.2-43$ & $\begin{array}{l}\text { This } \\
\text { study }\end{array}$ \\
\hline
\end{tabular}


Table 10B. Comparison of $\mathrm{Cu}, \mathrm{Ni}, \mathrm{Cr}, \mathrm{Cd}, \mathrm{Pb}$ concentration $(\mu \mathrm{g} / \mathrm{g})$ in $R$. prinoides leaves with other medicinal plant leaves.

\begin{tabular}{|c|c|c|c|c|c|c|c|}
\hline \multirow[t]{2}{*}{ Medicinal Plant } & \multirow[t]{2}{*}{ Origin } & \multicolumn{6}{|c|}{ Concentration $(\mu \mathrm{g} / \mathrm{g})$ of metals in medicinal plants } \\
\hline & & $\mathrm{Cu}$ & $\mathrm{Ni}$ & $\mathrm{Cr}$ & $\mathrm{Cd}$ & $\mathrm{Pb}$ & Ref. \\
\hline $\begin{array}{l}\text { Taraxacum officinale } \\
\text { Weber }\end{array}$ & Spain & 27 & - & - & - & 7 & 27 \\
\hline $\begin{array}{l}\text { Eucalyptus globulus } \\
\text { Labill }\end{array}$ & Spain & 10 & - & - & - & 6 & 27 \\
\hline Plantago major L. & Bulgaria & 13 & - & - & - & 6 & 27 \\
\hline Mentha piperita $\mathrm{L}$. & Bulgaria & 19 & - & - & - & 8 & 27 \\
\hline Matricaria chamomilla $\mathrm{L}$. & Egypt & 20 & - & - & - & 3 & 27 \\
\hline Calotropis procera Ait. & Nigeria & 137.8 & 235.2 & 198.6 & - & - & 28 \\
\hline Acalypha wilkensiana & Nigeria & 146.1 & 203.6 & 34.6 & - & - & 28 \\
\hline Euphorbia hirta Linn. & Nigeria & 234.8 & 241.1 & - & - & - & 28 \\
\hline Marjorana hortensis L. & Egypt & 3.95 & 25.25 & 2.15 & 2.05 & 14.4 & 29 \\
\hline $\begin{array}{l}\text { Gynostemma } \\
\text { pentaphyllum }\end{array}$ & Thailand & $5.141-15.48$ & $0.530-6.600$ & $0.434-12.42$ & $0.021-4.772$ & $0.361-64.40$ & 30 \\
\hline Camellia sinensis & Thailand & $3.075-22.42$ & $2.281-9.194$ & $0.205-10.54$ & $0.002-0.100$ & $0.060-53.89$ & 30 \\
\hline Morus alba & Thailand & 5.724-11.09 & $0.368-2.171$ & $0.250-1.419$ & $0.001-0.022$ & $0.118-1.185$ & 30 \\
\hline Catha edulis Forsk & Ethiopia & $1.85-5.53$ & - & $0.66-3.47$ & - & - & 31 \\
\hline $\begin{array}{l}\text { Thymus schimperi and } \\
\text { Thymus vulgaris }\end{array}$ & Ethiopia & $7.69-9.3$ & $9.83-14.2$ & - & $0.87-1.3$ & - & 32 \\
\hline Croton macrostachyus & Ethiopia & 6-19 & $3-26$ & $21-87$ & $0.75-1.08$ & $10-22$ & 33 \\
\hline R. prinoides & Ethiopia & $6.5-73.0$ & $12.8-27.3$ & $5.08-20.6$ & $0.81-3.10$ & $17.7-25.0$ & $\begin{array}{l}\text { This } \\
\text { study }\end{array}$ \\
\hline
\end{tabular}

\section{CONCLUSIONS}

Generally, the concentrations of the metals were higher in $R$. prinoides leaf than in stem samples. The concentration difference of all the metals among sample sites both for leaf and stem samples were statistically significant which implies that the difference in concentration of the metals was not attributed to the random errors during sample preparation and analysis. In general this study showed that the leaf and stem of $R$. prinoides (Gesho), which are used in the preparation of traditional alcoholic beverages in Ethiopia, are good sources of essential minerals and virtually free from toxic metals. The levels of metals $R$. prinoides are in good agreement with the most of reported values for all the studied metals except $\mathrm{Mn}$ and Fe which are lower in the leaves of $R$. prinoides than in the leaves of most other medicinal plants.

Since $R$. prinoides is a cash crop and widely used for the bitterness of local alcoholic beverages in Ethiopia and indeed, it is a potential for commercial alcoholic beverages the assessment of levels of essential and heavy toxic metals is particular interest with respect to human health and the quality of its products. Thus, the present study will give brief information about the mineral contents of it.

\section{ACKNOWLEDGEMENTS}

The authors express their gratitude to the Department of Chemistry, Addis Ababa University, Ethiopia, for providing the laboratory facilities. Afewerk Gebre is thankful to Tigray Education Bureau, Ethiopia, for sponsoring his study. 


\section{REFERENCES}

1. Dlamini, M.D.; Turner, S. Rhamnus prinoides L'Hérit, Witwatersrand National Botanical Garden: South African National Biodiversity Institute, South Africa; 2002.

2. Alemu, H.; Abegaz, B.M.; Bezabih, M. Bull. Chem. Soc. Ethiop. 2007, 21, 189.

3. Abegaz, B.M.; Ngadjui, B.T.; Bezabih, M.; Mdee, L.K. Pure Appl. Chem. 1999, 71, 919.

4. Rhamnus prinoides L'Hérit. Agroforestry Database 4.0, 2009, 1-5.

5. Engels, J.M.M.; Hawkes, J.G.; Melaku, W. Plant Genetic Resource of Ethiopia, Cambridge University Press: Camridge Books Online; 1991; p 42.

6. Abegaz, B.M. Bull. Chem. Soc. Ethiop. 1996, 10, 57.

7. Tigray Livelyhood Zone Reports, Gesho and Wheat Highland Zone, Livelihood Profile Tigray Region, Ethiopia, 2007.

8. Nindi, M.M.; Kgarebe, B.V.; Wolfender, J.L; Abegaz, B.M. Phytochem. Anal. 1999, 10, 69.

9. Muzila, A.; Msagati, T.A.M.; Abegaz, B.; Nindi, M.M. Characterization of Geshodin-metal complexation by electrospray-mass spectrometry, $11^{\text {th }}$ NAPRECA Symposium, Book of Proceedings, Antananarivo, Madagascar; 2010; pp 35-44.

10. Pavlik, J.W. ARKIVOC, 2007, 9, 1.

11. Hayeshi, R.; Mukanganyama, S.; Hazra, B.; Abegaz, B.; Hasler, J. Phytother. Res. 2004, 18, 877.

12. Kiringe, J.W. Ethnobot. Res. Appl. 2006, 4, 61.

13. Crowch, M.C.; Okello, E.J. Afr. J. Pharm. Pharmacol. 2009, 3, 469.

14. Njoroge, G.N.; Bussmann, R.W. J. Ethnobiol. Ethnomed. 2006, 2, 54.

15. Teklehaymanot, T.; Giday, M. J. Ethnobiol. Ethnomed. 2007, 3, 12.

16. Muregi, F.W.; Ishih, A.; Suzuki, T.; Kino, H.; Amano, T.; Mkoji, G.M.; Miyase, T.; Terada, M. Phytother. Res. 2007, 21, 337.

17. Adeyeye, E.I. Bull. Chem. Soc. Ethiop. 2005, 19, 175.

18. Abdullahi, M.S.; Uzairu, A.; Okunola, O.J. Afr. J. Biotechnol. 2008, 7, 1526.

19. Nabrzyski, M. Mineral Components in Foods in Chemical and Functional Properties of Food Components Sereies, Szefer, P.; Nriagu, J.O. (Eds.). CRC Press: Boca Raton; 2006.

20. Eurachem Working Group EURACHEM Guide The Fitness for Purpose of Analytical Methods, 1998. LGC (Teddington) Ltd: UK; 1998; pp 1-61.

21. Ewing, G.W. Instrumental Methods of Chemical Analysis, 5th ed., McGraw-Hill: New York; 1985.

22. Wood, J.M. Environ. Health Perspect. 1985, 63, 115.

23. Soetan, K.O.; Olaiya C.O.; Oyewole O.E. Afr. J. Food Sci. 2010, 4, 200.

24. Jung, M.C. Sensors 2008, 8, 2413.

25. Jayakumar, K.; Jaleel, C.A. Bot. Res. Intern. 2009, 2, 310.

26. Miller, J.N.; Miller, J.C. Statistics and Chemometrics for Analytical Chemistry, 4th ed., Pearson Practice Hall: England; 2000.

27. Rashed, M. J. Arid Environ. 1995, 29, 185.

28. Obiajunwa, E.; Adeleke, A.; Olanrewaju, O. J. Radioanal. Nucl. Chem. 2002, 252, 473.

29. Lokhande, R.; Singare, P.; Andhele, M.; Acharya, R. Radiochem. 2009, 51, 321.

30. Al Moaruf, O.; Muibat O.; Asiata O.; Isiaka A.; Nureni, O. Food Chem. 2004, 85, 67.

31. Atlabachew, M.; Chandravanshi, B.S.; Redi, M. Biol. Trace Elem. Res. 2010, 138, 316.

32. Derbie, A.; Chandravanshi, B.S. Biol. Trace Elem. Res. 2011, 141, 317.

33. Aregahegn, A. M.Sc. Thesis, Determination of essential, non-essential and toxic metals in Croton macrostachyus leaves and its infusion (a traditional medicinal plant in Ethiopia), Addis Ababa University, Ethiopia, 2010. 